\title{
Paternity and Parenting in the Context of Eating Disorders: An Integrative Literature Review*
}

\author{
Michel da Matta Simões** (1) \& Manoel Antônio dos Santos (1) \\ Universidade de São Paulo, Ribeirão Preto, SP, Brasil
}

\begin{abstract}
Family relationships seem to have relevant contribution to the etiopathogenesis of Eating Disorders (EDs). This study aimed to analyze the scientific production about the paternity and parenting experiences of fathers whose daughters developed EDs. The literature review was conducted through the databases LILACS, PubMed, PsycINFO, Web of Science and EMBASE, in the period from 1999 to 2019. From the 878 retrieved papers, 23 were selected for the analysis. The results show that paternity and parenting experiences are influenced by father's personality traits. The dominant representation is of an affectionless and not empathetic father, as well as punitive and insensitive to the daughter's emotional needs. Knowing the paternal experiences is central to subside sensible care to both, daughters' and fathers' demands.
\end{abstract}

KEYWORDS: eating disorders, fathers, paternity, parenting, father-child relations

\section{Paternidade e Parentalidade no Contexto dos Transtornos Alimentares: Revisão Integrativa da Literatura}

\begin{abstract}
RESUMO - Relações familiares parecem ter uma contribuição relevante na etiopatogenia dos transtornos alimentares (TAs). Este estudo teve por objetivo analisar a produção científica sobre as vivências de paternidade e parentalidade de pais cujas filhas desenvolveram TAs. O levantamento bibliográfico foi realizado a partir das bases LILACS, PubMed, PsycINFO, Web of Science e EMBASE, no período 1999-2019. Dos 878 estudos recuperados nas buscas, 23 foram selecionados para análise. Os resultados evidenciam que as vivências de paternidade/parentalidade são influenciadas pela personalidade paterna. A representação dominante é de um pai pouco afetuoso e desprovido de empatia, punitivo e insensível às necessidades emocionais das filhas. Conhecer as vivências paternas é fundamental para subsidiar um cuidado sensível às demandas das filhas, assim como às dos pais.
\end{abstract}

PALAVRAS-CHAVE: distúrbios do ato de comer, pai, paternidade, parentalidade, relações pai-criança

\section{INTRODUCTION}

Eating Disorders (EDs) characterize serious changes and disturbances in eating behavior, of multifactorial etiology, which imply risks to physical health and psychosocial functioning, which can negatively affect various aspects of the affected person's life (American Psychiatric Association, 2014; Treasure \& Schmidt, 2013). The prevalence according to international estimates is of 657 cases per 100,000 women for Anorexia Nervosa (AN) and 1,225 cases per 100,000 women for Bulimia Nervosa (BN) (Smink, van Hoeken, \& Hoek, 2012). In Brazil, there are no official data available or scientific studies on the prevalence of EDs in the population. However, a study carried out by the São Paulo Department of Health in 2014 highlighted that $77 \%$ of young women were prone to the development of some type of ED; in addition, every two days, on average, a person is hospitalized for AN or BN in hospitals linked to the Unified Health System

\footnotetext{
* The first author is supported by CAPES through a funding grant (88887.600237/2021-00). The second author is supported by CNPq through a productivity in research funding.

** E-mail: michelsimoespsi@gmail.com

- Submitted: 29/01/2020; Accepted: 27/09/2020
} 
(Portuguese acronym: SUS) in the State of São Paulo (Health Department of the State of São Paulo, 2014).

Studies highlight the high incidence and mortality rates associated with ED, resulting from physical and health complications caused by the disorder, as well as by the psychological and behavioral changes triggered (Campana, Tavares, \& Garcia Júnior, 2012; Fava \& Peres, 2011; Fichter \& Quadflieg, 2016; Leonidas \& Santos, 2013b; Leonidas, Crepaldi, \& Santos, 2013; Smink \& Van Hoeken, 2013). Such evidences underscore the importance of developing prevention, intervention and health promotion strategies that focus on eating behavior patterns and ideals of body, weight and body shape disseminated in the contemporary era, as measures to reduce negative family repercussions of the disorder (Goulart \& Santos, 2012, 2015; Leonidas \& Santos, 2020; Leonidas, Nazar, Munguía, \& Santos, 2019; Santos, Garcia, \& Liontino-Santos, 2015).

In studies developed in recent decades, family has emerged as a key element for understanding the psychological aspects related to the development of EDs and the maintenance of symptoms (Attili et al., 2009; Espíndola \& Blay, 2009; Siqueira, Santos, \& Leonidas, 2020; Treasure $\&$ Schmidt, 2013). A body of growing evidence has been built about the impact that the family has on the production of these clinical conditions. The family context, it is important to say, also emerge as a source of social support and coping resources and, as such, the family has been considered a strategic ally of health professionals in monitoring the affected person (Souza \& Santos, 2015). The relatives of the person in mental distress have potential elements to work as a possible protection and support network for the continuity of treatment (Leonidas \& Santos, 2013a; Souza \& Santos, 2009, 2012), which tends to be long and subject to periods of higher difficulty and instability (Campbell \& Peebles, 2014; Leonidas \& Santos, 2014; Santos et al., 2015; Scorsolini-Comin \& Santos, 2012; Valdanha-Ornelas $\&$ Santos, 2016a; Valdanha et al., 2013).

The particular importance that the family acquires in the course of treatment and its unconscious implication in the symptoms associated with EDs is evident as several studies demonstrate that the bonds established by people diagnosed with these disorders are characterized by an insecure and ambivalent attachment style (Ciao et al., 2015; HerpertzDahlmann, 2015; Moura, Santos, \& Ribeiro, 2015). Thus, families with a member diagnosed with AN report difficulty in the relationship with the affected member and numerous damages in family functioning at different levels (Münch, Hunger, \& Schweitzer, 2016).

Studies show that welcoming the family allows to demystify and clarify information, beliefs, conceptions and fantasies that eventually permeate the imaginary and understanding of family members and the patient himself about the disorder, as well as to clarify the vicissitudes of the relationships and configurations that are established before and after the problem appears (Espíndola \& Blay, 2009; Lindstedt, Neander, Kjellin, \& Gustafsson, 2015).
Family involvement in treatment is beneficial not only from the point of view of the evolution of the condition and recovery of the person diagnosed with some ED, but also to promote favorable changes in family dynamics. When included in the treatment, family members tend to experience a reduction in burden and resolution of feelings of impotence and helplessness that they experience (Ramos \& Pedrão, 2013; Santos, Leonidas, \& Souza-Costa, 2016).

Considering the growing importance attributed to the place of the family in the treatment of EDs (Leonidas \& Santos, 2015a), it is relevant to take a closer look at aspects related to the roles played by each family member, as well as the repercussions of the characteristics of family relationships in the illness and recovery process (OliveiraCardoso et al., 2018; Valdanha et al., 2013). In this sense, it is observed that the maternal figure has concentrated the interest of researchers in the production about the subject (Ciao et al., 2015; Leonidas \& Santos 2015b; Moura et al., 2015).

Only in recent years studies have turned the attention to the influence of the father figure in anorexia and bulimia in young people who present these diagnostic configurations (Costa \& Santos, 2016). However, there is still a lack of systematization of the literature produced in this field. In the present study, paternity is understood as the condition of being or becoming a father, which is constituted in the social context and involves cultural and historical aspects that shape the psycho-affective process in which the father is supposed to perform various tasks, such as offering protection, contributing to their children's development and growth (Strauch, 2013). Parenting, in turn, is the exercise of the functions of care, education and discipline in the raising of a developing individual, and can also be equally performed by people other than biological parents (Gorin et al., 2015). Indispensable for the development of any human being, parenting assists children in their process of constitution as a subject, introducing and situating them in the family and society (Palermo et al., 2016). Although different, both concepts are closely related, because the way the individuals understand and experiences paternity is based on the relationship with the children and their intergenerational experiences, which will guide their behavior and their parenting style.

The clinical manifestations of EDs are crossed by issues related to paternity and the identification processes with parental figures, as well as the specificities of care relationships (Costa \& Santos, 2016). Thus, there is a need to produce knowledge about these dimensions related to the father figure, as well as his relationship with his daughter and her psychopathological condition. However, aspects of the father-daughter relationship in the EDs have been neglected by literature (Costa \& Santos, 2016), and the number of studies that addresses this theme is also significantly lower compared to the researches that aimed to investigate the mother-daughter relationship and the effects resulting from this bond (Salafia, Schaefer, \& Haugen, 2014). 
The scarcity of studies that address the father-daughter relationship is incongruous with the affective-emotional importance of the father figure and its possible contribution to the plot of unconscious fantasies that support the symptoms of EDs. Amianto et al. (2015) point out the association between the father's personality traits and the daughter's symptom levels and, according to Nielsen (2014), the daughter's perception of her relationship with her father plays a significant role in the development and maintenance of EDs. Geraldo and Lange (2017) indicate that, in many cases of $\mathrm{AN}$, the paternal function is absent or compromised. A research associates the quality of fatherdaughter relationship to the severity of symptoms (Salafia et al., 2014).

Considering that the integrative literature review is the most appropriate strategy to synthesize the knowledge produced in the national and international context about the exercise of the paternal function and parental care in families living with anorexia or bulimia, this study aimed to analyze the production and scientific knowledge about the paternity and parenting experiences of fathers whose daughters developed EDs.

\section{METHOD}

This study consists of a documentary, descriptive and retrospective research, which had the time frame from 1999 to 2019, in order to assure the operationalization of a manageable number of studies without ceasing to be comprehensive enough. The integrative review was chosen because this method allows to synthesize knowledge and discuss the objectives, methods, data sources and results obtained, making it possible to draw conclusions regarding the investigated knowledge area (Leonidas \& Santos, 2012, 2014; Soares et al., 2014).

In order to achieve the objective of the study, the six steps proposed by Broome (2000) were fulfilled, which consist of: 1 - elaboration of the guiding question; 2 - systematic search in literature, about the father-daughter relationship in the context of EDs; 3 - data collection; 4 - categorization of studies; 5 - critical and descriptive analysis of results and interpretation; 6 - synthesis of knowledge and identification of gaps in scientific production.

The following guiding question was elaborated: "What is the scientific evidence on the experience of paternity and parenting exercised by fathers of young people diagnosed with EDs?" Data collection was performed in journals indexed in regional and international indexing bases, namely: LILACS, PubMed, PsycINFO, Web of Science and EMBASE. The choice of these bases is justified because they are widely recognized by the scientific community and because they cover a wide spectrum of the regional and international literature, which allows ensuring the desirable scope of access to primary sources.

Data collection took place on a single day in January 2020 , being preceded by a thorough construction work and prior testing of the search strategy. The strategy was tested and refined in order to optimize the searches using combinations of controlled descriptors.

The initial selection of studies was carried out by two independent reviewers, who reviewed the titles and abstracts according to the established inclusion criteria, using Rayyan (Ouzzani et al., 2016), an online reference manager which assists in the selection of articles according to the previous established criteria. Indexed articles were searched using the descriptors available in Health Sciences Descriptors
(Portuguese acronym: DeCS) and Medical Subject Headings $(\mathrm{MeSH})$, as well as the "entry terms" and other keywords used in studies that address the theme. In order to select and organize the primary studies, EndNote Basic software (Clarivate Analytics) was used. At first, duplicate studies and those that were consistent with the exclusion criteria were removed.

Different descriptor arrangements were used in the search strategy with the Boolean operators AND and OR. In order to operationalize the searches, the system [information omitted to avoid authorship identification] was used, a network of online services that allows access to the databases and the contents of indexed journals, allowing extracting the articles in full. Through these procedures, the authors had access to all selected articles.

In the bibliographic search, the following inclusion criteria were adopted for the retrieval of articles: (a) empirical studies that addressed the topic of EDs; (b) written in Portuguese, English or Spanish; (c) with publication date between January 1999 and December 2019; (d) that they were primary studies; (e) which made the summary available in the databases used; and (f) that directly addressed the relationship between father and child diagnosed with ED. As exclusion criteria it was established: (a) presentation in the form of a dissertation, thesis, book, book chapter, manual, editorial, news, criticism, review, letter or comment; (b) literature review studies; (c) articles that did not include neither the father nor the child as participants - for example, data on the father-child relationship obtained only from other sources, such as the mother/siblings of the person affected. Regarding the population, studies related to children's family contexts and research carried out with health professionals were excluded.

A flowchart was prepared according to the PRISMA guidelines (Guidelines for Reporting of Systematic Review) (Moher et al., 2009) for the description of the literature search process and the report of the study inclusion process. The recommended steps for selecting the articles were followed: the reviewers evaluated the articles independently by reading the titles and abstracts, according to the established inclusion and exclusion criteria. The 
Kappa coefficient, of inter-evaluators agreement (Vieira $\&$ Garrett, 2005), was calculated to assess the substantial agreement between the reviewers. After this initial selection process, the selected articles were recovered in full. The studies were then read to assess their eligibility. In this step, the articles were submitted to an analytical reading carried out independently by the two reviewers. The articles selected by this screen constituted the corpus of the research.

The CASP (Critical Appraisal Skills Programme) criteria were used to assess the quality of the included studies, an instrument designed to evaluate qualitative research. Then, the reviewers collated their assessments and checked for possible divergences, which were resolved based on discussion in order to reach a consensus between them. The results were organized in a spreadsheet containing six dimensions of analysis, to enable categorization according to the procedures suggested by Broome (2000). The dimensions of analysis were as follows: (a) year of publication; (b) source of publication; (c) type of study; (d) sample; (e) objectives and (f) main results. The results of the analysis that reached consensus were automatically accepted. Disagreeing analyses were discussed on a case-by-case basis until a common agreement was reached. In addition, as part of the analysis of the articles, the level of scientific evidence for each one was determined, based on the criteria recommended by Phillips et al. (2001).

Subsequently, the information extracted from the articles was organized and submitted to content analysis (Minayo, 2013). The analysis was carried out through three steps: 1- pre-analysis; 2- exploration of the material; 3- treatment of the obtained results.

\section{RESULTS AND DISCUSSION}

Figure 1 shows the flowchart, prepared according to the PRISMA recommendations, which details the path taken from the initial search in the databases to the selection of articles that make up the corpus of this review. The calculated Kappa coefficient was considered satisfactory (0.86). Initially, 878 abstracts were found that corresponded to the descriptors used in the searches. After reading the titles and abstracts and, later, the studies selected to be read in full, 23 met the inclusion and exclusion criteria of the study. All selected articles were available in full, being accessed through [information omitted to avoid identifying the authorship]. Of the total number of titles and abstracts selected, the largest number was found in the PubMed database, totalizing 583, with the LILACS database returning the lowest number (four). After completing the steps of screening and selection of articles, it was observed that most of the studies that make up the corpus of the review came from the Web of Science base, whereas, of the results initially obtained through EMBASE, none was selected to compose the review. The LILACS database had the lowest number of selected studies, with only one article. Additionally, one article was inserted by manual search, because it was previously known, as it had been cited in one of the selected articles, met the established inclusion/ exclusion criteria, but it was not indexed in the consulted databases. In some cases, the articles' descriptors are not elaborated in accordance to the terms conceived by the $\mathrm{DeCS}$ or $\mathrm{MeSH}$, which can result in studies that address the theme of interest not being retrieved during the search in the indexing bases.

The reviewed articles were distributed in a wide variety of scientific journals, with no journal predominating over others. In relation to journals, most articles are concentrated in medical journals, totalizing $11(47.82 \%)$, nine of which were published in psychiatric journals (39.14\%). Then, the second largest area of concentration of journals is that of psychology, with nine articles (39.14\%). Finally, three articles $(13.04 \%)$ were published in journals identified as multidisciplinary. Despite the fact that most scientific journals focus on the medical field, when only those with more than one article in the review corpus are observed, the area of psychology predominates.

With regard to the country of origin of the studies selected to compose the corpus of this review, the United Kingdom and Italy are the countries that stood out the most in number of studies related to the topic of interest, with four studies each (if added, it corresponds to $34.78 \%$ of the articles). Only one study is signed by authors exclusively from the United States. However, three studies are coauthored by American researchers, in collaboration with authors from Australia, Canada and Israel, so that the country has participation in four of the 23 articles analyzed, followed by Spain (three), Israel (two), Poland (two), Austria, China and Turkey, with one study each. Finally, Brazil is the only South American country included in the list of country of origin of publications, with one study (Santos \& Zanotti, 2016).

As for the language in which the selected articles were written, almost all studies were published in English (95.65\%). Only one article was written in Portuguese and none in Spanish. As for the year of publication, the selected studies were published in the period from 2003 to 2019 . The last decade concentrates most of the articles, so that $19(82.6 \%)$ of the 23 analyzed productions were published between 2009 and 2019. The years of 2013 and 2018 were the ones with the largest number of publications in the topic of interest in this integrative review, with three articles each. The others had the following distribution per year: 2003 (1), 2006 (1), 2008 (2), 2009 (2), 2010 (1), 2012 (2), 2014 (2), 2015 (2), 2016 (2), 2017 (1) and 2019 (1). 


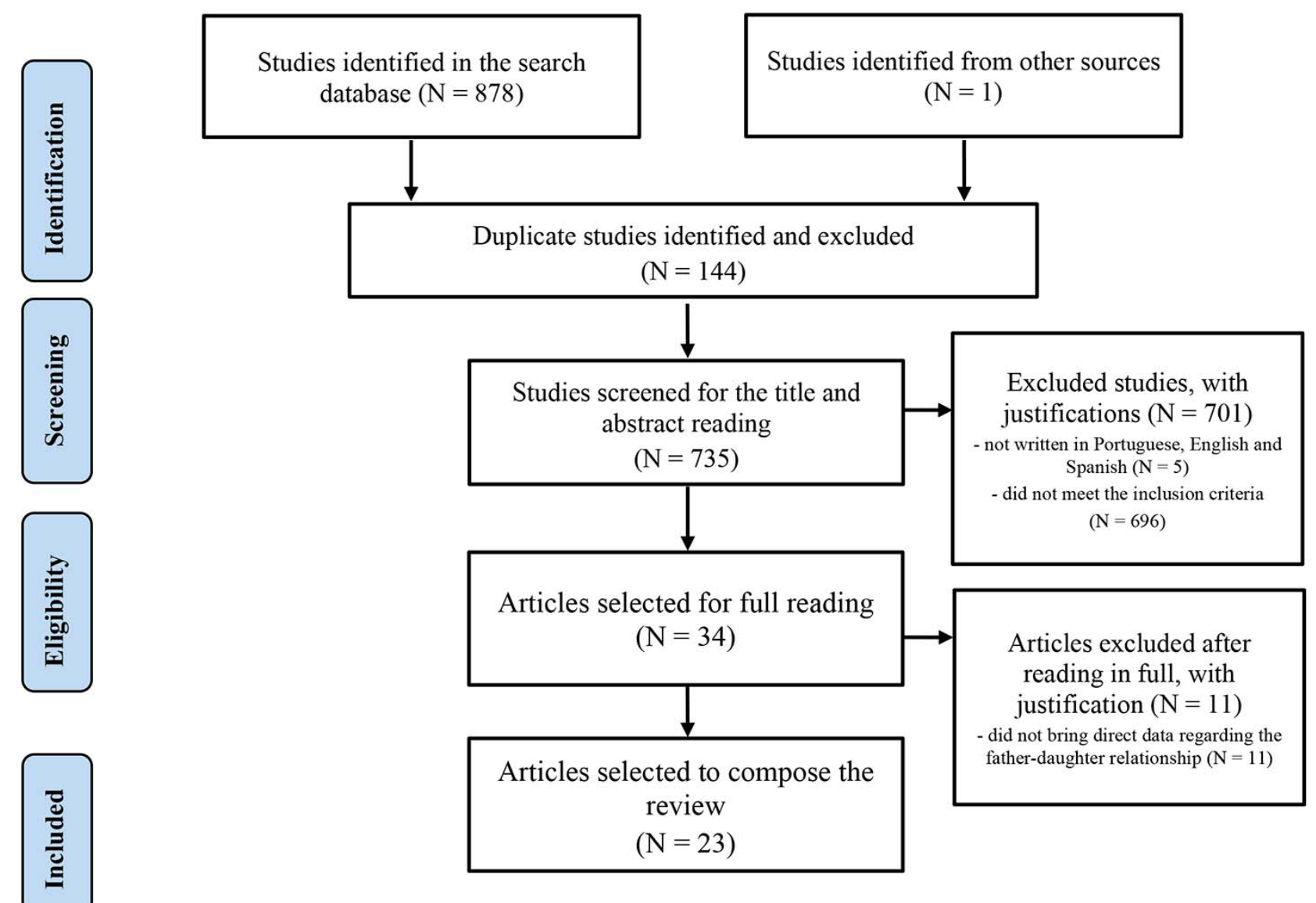

Figure 1. Flowchart of the integrative review, prepared according to the PRISMA guidelines.

Source: prepared by the authors.

Regarding the studied population, great variability was noted, from a case study composed by a single triad (father, mother and daughter) to 233 triads. As for the methodological design, of the total, 16 studies used quantitative methods, while seven used a qualitative approach. The level of evidence (LE) was assessed according to the classification proposed by Phillips et al. (2001). The results showed: 12 articles with LE $2 b$, a level that corresponds to cohort studies (including lower quality randomized clinical trial); six articles with LE $3 b$, which includes case-control studies; and five articles classified with LE 4 (case series), which suggests that studies do not have substantial Les yet.

It is also observed that most studies address the father-daughter relationship in the context of EDs through quantitative methods, in addition to the predominance of descriptive and correlational studies. Only two studies have a longitudinal design, which is the least frequent study design in the articles that comprised the review corpus. Among the studies with participants that had some type of ED, the most frequent diagnoses were $\mathrm{AN}$ and $\mathrm{BN}$. Most studies highlight the triad father, mother and daughter or the family as a population, indicating that studies that propose to analyze issues related to the relationship between father and daughter do so mostly from data from the family group, showing the importance attributed to triangulation in this context.
From the reading and critical analysis of the selected articles, the themes that made it possible to categorize the results obtained were identified and, thus, delimited the axes that guided the primary studies, namely: Paternal Personality Traits, Paternity Nuances, Parenting Experience and Family Dynamics. These categories concentrate 20 themes, which are not mutually exclusive, since each article can address more than one identified theme. The category with the highest number of themes concerns the personality traits of fathers of young people with ED, comprising 35\% of the identified themes; the most recurrent result of the studies is the emotional distance, present in $39.13 \%$ of the publications, being listed in the category that deals with the nuances of paternity. Then, the themes "absent father", "paternal overprotection", "importance of paternal involvement in treatment" and "transgenerationality" were the most present (21.73\% of articles each).

The category Paternal Personality Traits concerns the attributes and characteristics that the father presents regarding himself in the relationship with the world and with other people, characterizing certain lasting and prevailing patterns of behavior, thoughts and feelings. The themes identified were: "overprotective behavior" $(\mathrm{n}=5)$, "difficulties in relating to other people" $(\mathrm{n}=3)$, "avoidant behavior" $(n=2)$, "immaturity" $(n=2)$, "difficulties in 
interpersonal communication" $(\mathrm{n}=2)$, "selfishness" $(\mathrm{n}=1)$ and "authoritarianism" $(\mathrm{n}=1)$. It is important to state that the themes are not mutually exclusives, in such a way that a theme does not preclude the other and the same article can compose more than one theme.

The studies indicate that fathers of young people with EDs have difficulties in relating to other people. Balottin et al. (2017) found damages in the affective quality of the interaction between fathers and daughters, due to the difficulty of getting in deep contact with each other and sharing affections. In accordance with this profile, Özyurt et al. (2018) analyze a case in which the father's dynamics is permeated by problems to express and share pleasures and affections. This difficulty can be evidenced through behaviors exhibited by fathers of young people with anorexia, such as tendency to isolation and the practice of more solitary activities (Treasure, Schmidt, \& Kan, 2019).

Knowing the importance of communication for the development of healthy bonds, such problems in relating to other people can, at least in part, be understood in the light of the findings of Wallis et al. (2018), who identified difficulties in interpersonal communication of fathers. In the same perspective, Treasure et al. (2019) draw attention to the fact that fathers recognize that improving communication skills could be a useful and valuable tool, both for the relationship with their daughters and for the relationship with others in general.

More specifically, the analysis of the reviewed studies allowed the identification of overprotective behavior by the fathers, as well as escape and avoidance behaviors, with characteristics of immaturity, selfishness and authoritarianism. Overprotective behaviors are characterized by the father's excessive control and rigidity in relation to his daughter's private life. Such behaviors are perceived in a negative way by their daughters, who describe losses, especially with regard to their autonomy and preservation of their privacy. Furthermore, this personality pattern is reported together with the fathers' perception of being less empathetic and caring, in addition to being associated with the symptomatic intensity of EDs (Canetti et al., 2008; Horesh et al., 2015; Jones, Leung, \& Harris, 2006; Karwautz et al., 2003; Pilecki, Józefik, \& Salapa, 2014).

Still with regard to personality characteristics, there seems to have a relationship between avoidant behavior, selfishness and immaturity of the fathers of young people who have developed ED. Amianto et al. (2013) and Fassino, Amianto and Abbate-Daga (2009) describe avoidant behavior as composed of feelings of anxiety and fear, which stimulate escape and avoidance behaviors in situations perceived as threatening. In this context, selfishness can be understood as a protection and self-preservation resource for fathers in the face of these unresolved difficulties. Similarly, authoritarianism, identified in the study by Enten and Golan (2009) as inversely correlated with the perception of parents as competent by the daughters, also refers to a potential defensive resource, being a poorly elaborated way of trying to compensate for something that seems to be lacking or that immaturity does not allow organizing efficiently.

The Paternity Nuances category refers to characteristics and elements that permeate the relationship of the dyad, that is, the way in which father and daughter interact, the bonds they establish, the components of these bonds and the interactions that follow, as well as the particularities of exchanges established between them. The themes identified were: "emotional distance" $(\mathrm{n}=9)$, "absent father" $(\mathrm{n}=5)$, "bonding difficulties" $(\mathrm{n}=4)$, "instability" $(\mathrm{n}=4)$, "paternal rejection" ( $(\mathrm{n}=3)$, "hostility in the relationship" $(\mathrm{n}=2)$. Among the listed themes, emotional distancing stands out, clearly the most identified in different studies. In such a way, when bringing together the way in which the paternal emotional distance is defined, the representation that one has is of a punitive and little affectionate father (Horesh et al., 2015), insensitive (Amianto et al., 2013; Pilecki et al., 2014), with difficulties in connecting emotionally with the daughter (Hooper \& Dallos, 2012), emotionally unavailable (Elliott, 2010; Pace, Cacioppo, \& Schimmenti, 2012), little loving, little affectionate and little empathic, and with an impaired parental care relationship (Canetti et al., 2008; Dallos \& Denford, 2008; Karwautz et al., 2003). In view of these results, it is possible to observe a relationship between the emotional distance and the overprotective behavior of these fathers, since, besides being perceived and described as controlling and overprotective, they are also described as less empathic and affectionate by their daughters (Canetti et al., 2008; Horesh et al., 2015; Pilecki et al., 2014).

The theme absent father plays an important role in the category in question (Paternity Nuances). Mateos-Agut et al. (2014) point out that the father's little presence in the relationship with the daughter leads to the configuration of a distant relationship, which compromises the communication and the relationship of the dyad. Enten and Golan (2009) found that the time spent by the fathers at work was inversely correlated with the body mass index (BMI) of the young women who participated in the study, characterizing what the authors defined as "father hunger". Elliott (2010) finds that the participants in her study perceived the father as absent during adolescence and that this may have been detrimental to their development and individuation process. Balottin et al. (2017), when observing the interaction of the father-mother-daughter triad in families of adolescents with $\mathrm{AN}$, describe the non-participation and absence of the father in various activities of daily family life. The fathers of that study showed a preference for more solitary practices. This finding is also supported by the study by Santos and Zanotti (2016), which portrays the absence of the father in the patient's family life and proves that this distancing has a relationship with the psychopathological symptoms.

Regarding the bonding difficulties, Hooper and Dallos (2012) point out a bonding pattern that is characterized by the contempt and lack of involvement of the fathers. Among women with binge eating, Pace et al. (2012) describe the preponderance of an insecure and disturbed bond, which is 
closely associated with their clinical condition. Similarly, Elliott (2010) also presents data that suggest that the type of bond established by the father-daughter dyad is perceived as inconsistent and insecure, reinforcing uncertainty and the fear of abandonment. Mateos-Agut et al. (2014), in turn, portray an emotional connection defined as fragile, the result of a bond marked by insecurity and weakened by difficulties.

Instability also emerges as a point of difficulty in the father-daughter relationship, both as a cause and as a result of the problems that go through their coexistence as a dyad. Elliott's study (2010) examines data that demonstrate a predominance of father-daughter relationships marked by instability, contributing to perpetuate marks of uncertainty and insecurity in the way the daughter builds her bonds. Amianto et al. (2013) and Fassino et al. (2009) indicate this instability as a consequence of the father's immaturity, in combination with other personality traits, such as low persistence and inconsistency in behaviors and actions. Such characteristics and qualities of the relationship can lead the daughter to deal with her problems and concerns by herself, instead of resorting to help, because the instability that goes through the relationship with the father and his behaviors make it difficult for a feeling of trust and security to grow (Dallos \& Denford, 2008).

In addition, there are also cases in which the fatherdaughter relationship is marked by rejection, as described by Mateos-Agut et al. (2014), who also point out the influence of such behavior on the intensity of symptoms of patients with AN. Similarly, Elliott (2010) found data that indicate a relationship between the symptoms that characterize AN and the perception of paternal rejection. Jones et al. (2006) indicate the perception of paternal rejection in patients with $\mathrm{ED}$, which is associated with the adoption of behaviors of obsessive search for thinness, compensatory maneuvers typical of bulimia and intense dissatisfaction with the body.

Finally, hostility in the relationship, despite appearing marginally in the themes identified in this review, adds significant elements that complement the adversities that make up the category that deals with the paternity nuances. Treasure et al. (2019) describe a profile in which the father oscillates between refusal and hostility in the relationship and care for his daughter. In the same sense, the studies conducted by Horesh et al. (2015) point out that patients with EDs, when compared to a control group, describe the relationship with their fathers as more destructive, threatening and harmful, and tend to represent the relationship as based on accomplishments that did not prioritize reciprocal needs, maintaining a selfish character.

The category Parenting Experience deals with the way in which the father conceives his actions in the exercise of his paternal function, bringing together the set of activities he performs and the degree of participation in the daughter's life, as well as the influence he exercises in the subjective constitution of the teenager. The themes identified were: "importance of paternal involvement in the treatment" $(\mathrm{n}=5)$, "little involvement in the education and raising of the daughter" $(\mathrm{n}=4)$, "decay of the paternal function" $(\mathrm{n}=$ $4)$, "need for support and strengthening" $(n=2)$.

The reviewed literature demonstrates the beneficial effect and the importance of paternal involvement in the treatment of the daughter. It is worth mentioning that, in the last four years that this review covers (2015 to 2019), interest on this subject has clearly grown, so that all publications that present data related to this specific topic are within this short time interval. Anastasiadou et al. (2016) point to the importance of the father in the daughter's treatment as a potential support not only for her, but for the whole family as a treatment unit. $\mathrm{Ma}$ (2015) presents two cases in which the father's involvement and participation were fundamental to the promising evolution of the daughters' clinical condition, contributing to obtain gains in treatment in general, including the strengthening of subjective well-being of the parents themselves.

Similarly, Özyurt et al. (2018) report that, after obtaining the father's involvement and participation in a case of childhood anorexia, the patient's condition had a significant evolution. Finally, Treasure et al. (2019) describe a case in which the father's role was focused on a specific type of treatment for AN, in which the benefits are observed both in the patient's treatment and in the father's well-being, who also reports having obtained gains in the relationship with the daughter and the perception of ED.

The studies highlighted little involvement in the education and raising of the daughter. The responsibility for the care and education of the daughter is often entirely, or in large part, borne by the mother, so that the father's participation occurs at a minimal and formal level, and involvement in this area related to the young woman's subjective constitution is even below the minimum required (Ma, 2015; Martín et al., 2013; Özyurt et al., 2018; Treasure et al., 2019).

In view of what was observed in the analysis of the studies that make up the corpus of this review, it appears that the theme of the decay of the paternal function is, to some extent, related to the previous theme, because it concerns the distancing of the paternal figure from the family care and management nucleus, as well as a lack of credibility promoted by the father's disability in the exercise of his paternal function. Santos and Zanotti (2016) point out the father's difficulty in placing himself between the mother and the daughter, and to interpose the influence of his authority as a resource that outlines the psychic separation between the two, which marks the decay of the paternal image in the cultural context to which the case analyzed in the study is inserted. Reinforcing this observation, Ma (2015) points out the passivity and impotence of the fathers, denoting the fragility of their psychic constitution and the feeling of inferiority that they experience before the family. In the same perspective, Fassino et al. (2009) also found traits that portray the father's fragility before the family group. Dallos and Denford (2008) present results that describe the father's inability, in the cases investigated, to deal with and manage conflicts and intra-family relationships. The self-perception 
of personal incompetence that these fathers experience is accompanied by a feeling of rejection and contempt on the part of the wife, which feeds experiences of worthlessness and helplessness.

The analyzed literature also indicates the need for support and strengthening of fathers in the face of a complex condition such as EDs. In this sense, Wallis et al. (2018) expose the fathers' difficulty in dealing with the impact of the development process of daughters with AN and suggest that strengthening the support provided by health professionals to these fatherss may be important. In the same perspective, Korotana et al. (2018) emphasize the importance of making efforts to provide support and strengthen the relationship between the father and the daughter being treated for ED. However, they regret that little attention has been paid in the context of treatment to the singular ways in which the father responds and perceives his daughter's psychopathology.

Finally, the Family Dynamics category addresses the elements that constitute the family organization, as well as the particularities that characterize the family group and support the symbolic interactions and exchanges that occur between its members. The themes identified were: "transgenerationality" $(\mathrm{n}=5)$, “impoverished family relationships" ( $\mathrm{n}=2)$, "structural failures" (11).

With regard to the topic of transgenerationality, Canetti et al. (2008) signal the existence of transgenerational effects on parenting when it comes to EDs. In this sense, Pilecki and Józefik (2013) report the difficulty of the fathers of diagnosed young people to distance themselves from the history of their origin families, which impacts on the way their daughters experience issues related to autonomy and privacy, given the models reproduced. In another study, Pilecki et al. (2014) reinforce the correlation between the behavior of parents of young people with ED in the current family and the experiences of their origin families; the results obtained by these authors also corroborate the difficulty of these fathers in distancing themselves from the history of their origin family. Furthermore, the authors point out that, particularly in cases of bulimia, the father's assessment of his relationship with his daughter is influenced by his transgenerational inheritance. Similarly, Dallos and Denford (2008) identified the outline of a script by the father, with attempts to correct the negative experiences lived in the origin family, to break the non-metabolized transgenerational cycle. In the same perspective, Hooper and
Dallos (2012) point out that fathers of young people with EDs tend to shape care relationships with their daughters based on their childhood experiences with their families of origin, to protect them from negative and traumatic aspects of their past.

Considering these vicissitudes, the understanding of the effects of transgenerationality is of particular relevance within the Family Dynamics category, both as a source of knowledge about the family psychodynamics, and for the frequency with which the transgenerational phenomenon was identified and worked in the articles in this review. Transgenerationality can be defined as psychic contents that cross generations virtually intact, perpetuating themselves without the psychic elaboration that would be necessary for their metabolization by the new generation (Valdanha, Scorsolini-Comin, \& Santos, 2013; Valdanha-Ornelas \& Santos, 2016b).

It was observed that impoverished family relationships significantly affect the family and result in losses, both at the collective and individual levels. Thus, Wallis et al. (2018) report marked losses in the functioning of families of young people diagnosed with AN in several areas, such as difficulties in solving problems and conflicts, as well as in the establishment of limits, impulse control and behaviors self-regulation, leading fathers and mothers to describe family dynamics as problematic in many situations. In accordance with such evidence, Balottin et al. (2017) identified difficulties in the attention shared by the members of the studied families, as well as in the interactions between father and daughter and in the integration between the members to perform collective tasks and share information and feelings. The authors found that such problems tended to be intensified due to the high levels of conflict and tension that permeate the environment.

Comparing the differences between families with members diagnosed with ED and others without a diagnosis of any psychiatric disorder, Mateos-Agut et al. (2014) pointed out that there are similarities in the family structure of both groups. However, structural failures that occur in families that have a member diagnosed with ED are not identified in families free from mental disorders. According to the authors, there is a predominance of polarization between parents, which causes the family structure to be constituted in a compliant and passive way, or in a selfish and imposing way.

\section{CONCLUSION}

This study achieved its objective of analyzing the national and international scientific production on the experiences of paternity and parenting of fathers whose daughters developed EDs. Despite some advances in knowledge on the topic of paternity and parenting in the context of EDs, the scientific production that specifically addresses the parental family subsystem is still modest and disproportionately smaller when compared to the amount of studies dedicated to the relationship between mother and children with $\mathrm{AN}$ or $\mathrm{BN}$. The results show that the experiences are influenced by the paternal personality, with traits of remarkable immaturity and rigidity, contact difficulties and emotional distance in 
relation to the daughters. The dominant representation is that of a father who is not very affectionate and devoid of empathy, punitive and insensitive to the emotional needs of his daughters, resulting in an impaired parental care relationship, which becomes an aggravating factor for the clinical condition presented. Studies show that awareness of the father's experiences can support sensitive care to the demands of daughters and the fathers themselves.

From the systematic analysis of literature, some questions emerged that could not yet be answered by the studies examined, among which we can highlight: How do the fathers of young people with EDs signify paternity and parenting? How do these meanings guide their parenting actions and organize the affective relationships they establish with their daughters/sons affected by the disorder? What relationships can be established between the styles of parental care carried by the fathers and the dynamics of the eating symptoms of their children?

It is worth noting the scarcity of studies, both nationally and internationally, that aim to understand the father's experience and vision about paternity and parenting in the context of EDs. None of the articles analyzed directly addressed the concept of paternity or the father's perspective on his relationship with his daughter, on the disease or on his experiences and feelings as the father of a young woman with ED. How to understand the little attention paid to the father-daughter dyad in global literature? One hypothesis that can be suggested is the theoretical developmental bias and the etiologic model that, for decades, dominated the knowledge, since the seminal studies of Hilde Bruch (1978), which established that only the mother-daughter relationship would be one of the nuclear elements in EDs.

Given these gaps and confirmed the clinical relevance of the theme, it is necessary to undertake studies that aim to understand more specifically the way the father-children relationship is constituted from the perspective of both the father and the daughter/son, as well as questions related to the subjective dimensions of the father figure, the symbolic place that the father occupies in the family and the relationships and bonds established. There is scope to seek to understand the intergenerational and trangerational aspects that influence the way in which fathers conceive paternity and parental care, as well as family relationships.

Only one Brazilian study on the topic was found. Lack of knowledge in the local context signals the need for more research that addresses the father-daughter relationship to be produced in the Brazilian context. The results can contribute to the establishment of prevention and intervention strategies in health services that promote paternal involvement in the care, given the evidence, even if not yet fully consolidated by more robust studies, which can result in benefits and gains for the treatment. Finally, the potential for innovation that a study on the topic can offer should be highlighted, from valorization of the perspective of the father and his active participation in the search for the daughter's health improvement.

\section{REFERENCES}

American Psychiatric Association (2014). DSM-5: Manual diagnóstico e estatístico de transtornos mentais (M. I. C. Nascimento, P. H. Machado, R. M. Garcez, R. Pizzato, \& S. M. M. da Rosa, Trads.) (5. ed.). Artmed.

Amianto, F., Daga, G. A., Bertorello, A., \& Fassino, S. (2013). Exploring personality clusters among parents of ED subjects: relationship with parents' psychopathology, attachment, and family dynamics. Comprehensive Psychiatry, 54(7), 797-811. https://doi.org/10.1016/j.comppsych.2013.03.005

Amianto, F., Ercole, R., Marzola, E., Daga, G. A., \& Fassino, S. (2015). Parents' personality clusters and eating disordered daughters' personality and psychopathology. Psychiatry Research, 230(1), 19-27. https://doi.org/10.1016/j. psychres.2015.07.048

Anastasiadou, D., Sepulveda, A. R., Parks, M., Cuellar-Flores, I., \& Graell, M. (2016). The relationship between dysfunctional family patterns and symptom severity among adolescent patients with eating disorders: a gender-specific approach. Women \& Health, 56(6), 695-712. https://doi.org/10.1080/03 630242.2015.1118728

Attili, G., Di Pentima, L., Toni, A., \& Roazzi, A. (2018). High anxiety attachment in eating disorders: Intergenerational transmission by mothers and fathers. Paidéia (Ribeirão Preto), 28, e2813. http://dx.doi.org/10.1590/1982-4327e2813

Balottin, L., Mannarini, S., Mensi, M. M., Chiappedi, M., \& Gatta, M. (2017). Triadic interactions in families of adolescents with anorexia nervosa and families of adolescents with internalizing disorders. Frontiers in Psychology, 7, 2046. https://doi. org/10.3389/fpsyg.2016.02046
Broome, M. E. (2000). Integrative literature reviews for the development of concepts. In B. L. Rodgers \& K. A. Knafl (Eds), Concepts development in nursing: Foundations, techniques and applications ( $2^{\text {nd }}$ ed., pp. 231-250). W. B. Saunders.

Bruch, H. (1978). The golden cage: The enigma of anorexia nervosa. Harvard University Press.

Campbell, K., \& Peebles, R. (2014). Eating disorders in children and adolescents: state of the art review. Pediatrics, 134(3), 582-592. https://doi.org/10.1542/peds.2014-0194

Canetti, L., Kanyas, K., Lerer, B., Latzer, Y., \& Bachar, E. (2008). Anorexia nervosa and parental bonding: the contribution of parent-grandparent relationships to eating disorder psychopathology. Journal of Clinical Psychology, 64(6), 703716. https://doi.org/10.1002/jclp.20482

Ciao, A. C., Accurso, E. C., Fitzsimmons-Craft, E. E., Lock, J., \& Le Grange, D. (2015). Family functioning in two treatments for adolescent anorexia nervosa. International Journal of Eating Disorders, 48(1), 81-90. https://doi.org/10.1002/eat.22314

Costa, L. R. S., \& Santos, M. A. (2016). Cuidado paterno e relações familiares no enfrentamento da anorexia e bulimia. In: D. Bartholomeu, J. M. Montiel, A. A. Machado, A. R. Gomes, G. Couto, \& V. Cassep-Borges (Orgs.), Relações interpessoais: Concepções e contextos de intervenção e avaliação (pp. 253279). Vetor.

Dallos, R., \& Denford, S. (2008). A qualitative exploration of relationship and attachment themes in families with an eating disorder. Clinical Child Psychology and Psychiatry, 13(2), 305-322. https://doi.org/10.1177/1359104507088349 
Elliott, J. C. (2010). Fathers, daughters, and anorexia nervosa. Perspectives in Psychiatric Care, 46(1), 37-47. https://doi. org/10.1111/j.1744-6163.2009.00236.x

Enten, R. S., \& Golan, M. (2009). Parenting styles and eating disorder pathology. Appetite, 52(3), 784-787. https://doi. org/10.1016/j.appet.2009.02.013

Espíndola, C. R., \& Blay, S. L. (2009). Percepção de familiares sobre a anorexia e a bulimia: revisão sistemática. Revista de Saúde Pública, 43(4), 707-716. https://doi.org/10.1590/S003489102009005000035

Fassino, S., Amianto, F., \& Abbate-Daga, G. (2009). The dynamic relationship of parental personality traits with the personality and psychopathology traits of anorectic and bulimic daughters. Comprehensive Psychiatry, 50(3), 232-239. https://doi. org/10.1016/j.comppsych.2008.07.010

Fichter, M. M., \& Quadflieg, N. (2016). Mortality in eating disorders: results of a large prospective clinical longitudinal study. International Journal of Eating Disorders, 49(4), 391401. https://doi.org/10.1002/eat.22501

Geraldo, R. P. D. S. R., \& Lange, E. S. N. (2017). O declínio da função paterna na anorexia feminina. Subjetividades, 16(2), 34-45. https://doi.org/10.5020/23590777.16.2.34-45

Gorin, M. C., Mello, R., Machado, R. N., \& Féres-Carneiro, T. (2015). O estatuto contemporâneo da parentalidade. Revista da SPAGESP, 16(2), 3-15.

Goulart, D. M., \& Santos, M. A. (2012). Corpo e palavra: grupo terapêutico para pessoas com transtornos alimentares. Psicologia em Estudo (Maringá), 17(4), 607-617. https://doi. org/10.1590/S1413-73722012000400007

Goulart, D. M. \& Santos, M. A. (2015). Psicoterapia individual em um caso grave de anorexia nervosa: a construção da narrativa clínica. Psicologia Clínica, 27(2), 201-227.

Herpertz-Dahlmann, B. (2015). Adolescent eating disorders: update on definitions, symptomatology, epidemiology, and comorbidity. Child and Adolescent Psychiatric Clinics, 24(1), 177-196. https://doi.org/10.1016/j.chc.2014.08.003

Hooper, A., \& Dallos, R. (2012). Fathers and daughters: their relationship and attachment themes in the shadow of an eating disorder. Contemporary Family Therapy, 34(4), 452-467. https://doi.org/10.1007/s10591-012-9204-8

Horesh, N., Sommerfeld, E., Wolf, M., Zubery, E., \& Zalsman, G. (2015). Father-daughter relationship and the severity of eating disorders. European Psychiatry, 30(1), 114-120. https://doi. org/10.1016/j.eurpsy.2014.04.004

Jones, C. J., Leung, N., \& Harris, G. (2006). Father-daughter relationship and eating psychopathology: the mediating role of core beliefs. British Journal of Clinical Psychology, 45(3), 319-330. https://doi.org/10.1348/014466505X53489

Karwautz, A., Nobis, G., Haidvogl, M., Wagner, G., HafferlGattermayer, A., Wöber-Bingöl, C., \& Friedrich, M. H. (2003). Perceptions of family relationships in adolescents with anorexia nervosa and their unaffected sisters. European Child \& Adolescent Psychiatry, 12(3), 128-135. https://doi. org/10.1007/s00787-003-0319-1

Korotana, L. M., von Ranson, K. M., Wilson, S., \& Iacono, W. G. (2018). Reciprocal associations between eating pathology and parent-daughter relationships across adolescence: a monozygotic twin differences study. Frontiers in Psychology, 9, 914-931. https://doi.org/10.3389/fpsyg.2018.00914

Leonidas, C., \& Santos, M. A. (2012). Imagem corporal e hábitos alimentares na anorexia nervosa: uma revisão integrativa da literatura. Psicologia: Reflexão e Crítica, 23(3), 550-558. https://doi.org/10.1590/S1414-98932013000400008

Leonidas, C., \& Santos, M. A. (2013a). Redes sociais significativas de mulheres com transtornos alimentares. Psicologia: Reflexão e Crítica, 26(3), 561-571. https://doi.org/10.1590/S010279722013000300016
Leonidas, C., \& Santos, M. A. (2013b). Instrumentos de avaliação da imagem corporal e dos hábitos alimentares na anorexia nervosa: análise da produção científica. Psicologia: Ciência e Profissão, 33(4), 868-883. https://doi.org/10.1590/S141498932013000400008

Leonidas, C., \& Santos, M. A. (2014). Social support networks and eating disorders: an integrative review of the literature. Neuropsychiatric Disease and Treatment, 10,915-927. https:// doi.org/10.2147/NDT.S60735

Leonidas, C., \& Santos, M. A. (2015a). Family relations in eating disorders: the Genogram as instrument of assessment. Ciência \& Saúde Coletiva, 20(5), 1435-1447. https://doi. org/10.1590/1413-81232015205.07802014

Leonidas, C., \& Santos, M. A. (2015b). Relacionamentos afetivo-familiares em mulheres com anorexia e bulimia. Psicologia: Teoria e Pesquisa, 31(2), 181-191. https://doi. org/10.1590/0102-37722015021711181191

Leonidas, C. \& Santos, M. A. (2020). Symbiotic illusion and female identity construction in eating disorders: a psychoanalytical psychosomatics' perspective. Ágora: Estudos em Teoria Psicanalítica, 23(1), 84-93. https://doi.org/10.1590/180944142020001010

Leonidas, C., Crepaldi, M. A., \& Santos, M. A. (2013). Bulimia nervosa: uma articulação entre aspectos emocionais e rede de apoio social. Psicologia: Teoria e Prática, 15(2), 62-75.

Leonidas, C., Nazar, B. P., Munguía, L., \& Santos, M. A. (2019). How do we target the factors that maintain anorexia nervosa? A behaviour change taxonomical analysis. International Review of Psychiatry, 31(4), 403-410. https://doi.org/10.1080/09540 261.2019.1624509

Lindstedt, K., Neander, K., Kjellin, L., \& Gustafsson, S. A. (2015). Being me and being us: adolescents' experiences of treatment for eating disorders. Journal of Eating Disorders, 3(1), 9-19. https://doi.org/10.1186/s40337-015-0051-5

Ma, J. L. (2015). The father's roles in the recovery of young Chinese suffering from anorexia nervosa in two Chinese cities, Hong Kong and Shenzhen. Journal of Family Therapy, 37(1), 61-78. https://doi.org/10.1111/1467-6427.12037

Martín, J., Padierna, A., Aguirre, U., González, N., Muñoz, P., \& Quintana, J. M. (2013). Predictors of quality of life and caregiver burden among maternal and paternal caregivers of patients with eating disorders. Psychiatry Research, 210(3), 1107-1115. https://doi.org/10.1016/j.psychres.2013.07.039

Mateos-Agut, M., Garcia-Alonso, I., De la Gándara-Martín, J. J., Vegas-Miguel, M. I., Sebastian-Vega, C., Sanz-Cid, B., Martínez, E. M. \& Martin-Martinez, E. (2014). Family structure and eating behavior disorders. Actas Espanolas de Psiquiatria, 42(6), 267-280.

Minayo, M. C. S. (2013). O desafio do conhecimento: Pesquisa qualitativa em saúde (13. ed.). Hucitec.

Moher, D., Liberati, A., Tetzlaff, J., Altman, D. G., \& Prisma Group. (2009). Preferred reporting items for systematic reviews and meta-analyses: the PRISMA statement. PLOS Medicine, 6(7), e1000097. https://doi.org/10.1371/journal.pmed.1000097

Moura, F. E. G. A., Santos, M. A., \& Ribeiro, R. P. P. (2015). A constituição da relação mãe-filha e o desenvolvimento dos transtornos alimentares. Estudos de Psicologia (Campinas), 32(2), 233-247. https://doi.org/10.1590/0103166X2015000200008

Münch, A. L., Hunger, C., \& Schweitzer, J. (2016). An investigation of the mediating role of personality and family functioning in the association between attachment styles and eating disorder status. BMC Psychology, 4(1), 36-46. https://doi.org/10.1186/ s40359-016-0141-4

Nielsen, L. (2014). Young adult daughters' relationships with their fathers: review of recent research. Marriage \& Family Review, 50(4), 360-372. https://doi.org/10.1080/01494929.2013.879553 
Ouzzani, M., Hammady, H., Fedorowicz, Z., \& Elmagarmid, A. (2016). Rayyan: a web and mobile app for systematic reviews. Systematic Reviews, 5, article 210. https://doi.org/10.1186/ s13643-016-0384-4

Özyurt, G., Çağan-Appak, Y., Karakoyun, M., Eliaçık, K., \& Baran, M. (2018). Father's role in infantile anorexia. The Turkish Journal of Pediatrics, 60(5), 608-611. https://doi.org/10.24953/ turkjped.2018.05.024

Pace, U., Cacioppo, M., \& Schimmenti, A. (2012). The moderating role of father's care on the onset of binge eating symptoms among female late adolescents with insecure attachment. Child Psychiatry \& Human Development, 43(2), 282-292. https://doi. org/10.1007/s10578-011-0269-7

Palermo, F. R., Magalhães, A. S., Féres-Carneiro, T., \& Machado, R. N. (2016). Ambiente conjugal: repercussões na parentalidade. Cadernos de Psicanálise (Rio de Janeiro), 38(34), 129-148.

Phillips, B., Ball, C., Sackett, D., Badenoch, D., Straus, S, \& Haynes, D. (2001). Oxford Centre for Evidence-Based Medicine: levels of evidence (March 2009): grades of recommendation. Disponível em: http://www.cebm.net/?o=1025

Pilecki, M. W., \& Józefik, B. (2013). Perception of transgenerational family relationships: comparison of eating-disordered patients and their parents. Medical Science Monitor: International Medical Journal of Experimental and Clinical Research, 19, 1114-1124. https://doi.org/10.12659/MSM.889432

Pilecki, M. W., Józefik, B., \& Salapa, K. (2014). Correlations between the perception of family functioning by patients with eating disorders and their parents and the perception of relations in the parents' families of origin. Psychiatria Polska, 48(4), 789-808.

Salafia, E. H. B., Schaefer, M. K., \& Haugen, E. C. (2014). Connections between marital conflict and adolescent girls' disordered eating: parent-adolescent relationship quality as a mediator. Journal of Child and Family Studies, 23(6), 11281138. https://doi.org/10.1007/s10826-013-9771-9

Santos, K. M. C., \& Zanotti, S. V. (2016). A anorexia na clínica contemporânea: considerações sobre o sintoma. Estudos e Pesquisas em Psicologia, 16(4), 1239-1255. https://doi. org/10.12957/epp.2016.33447

Santos, M. A. (2006). Sofrimento e esperança: grupo de pacientes com anorexia e bulimia nervosas. Medicina (Ribeirão Preto), 39(3), 386-402.

Santos, M. A., Garcia, R. W. D., \& Liotino-Santos, M. (2015). A sujeição aos padrões corporais culturalmente construídos em mulheres de baixa renda. Demetra, 10(4), 761-774. https://doi. org/10.12957/demetra.2015.16117

Santos, M. A., Leonidas, C., \& de Souza-Costa, L. R. (2016). Grupo multifamiliar no contexto dos transtornos alimentares: a experiência compartilhada. Arquivos Brasileiros de Psicologia, 3(68), 43-58.

Secretaria de Saúde do Estado de São Paulo (2014). Distúrbio alimentar ameaça 77\% das jovens de SP. São Paulo: Assessoria de Imprensa. Disponível em: http://www.saude.sp.gov.br/ses/ noticias/2014/janeiro/disturbio-alimentar-ameaca-77-dasjovens-de-sp

Siqueira, A. B. R., Santos, M. A., \& Leonidas, C. (2020). Confluências das relações familiares e transtornos alimentares: revisão integrativa da literatura. Psicologia Clínica, 32(1), 123149. https://dx.doi.org/10.33208/PC1980-5438v0032n01A06

Smink, F. R., van Hoeken, D., \& Hoek, H. W. (2013). Epidemiology, course, and outcome of eating disorders. Current Opinion in Psychiatry, 26(6), 543-548. https://doi.org/10.1097/ YCO.0b013e328365a24f

Smink, F. R., van Hoeken, D, \& Hoek, H. W. (2012). Epidemiology of eating disorders: incidence, prevalence and mortality rates. Current Psychiatry Reports, 14(4), 406-414. https://doi. org/10.1007/s11920-012-0282-y

Soares, C. B., Hoga, L. A. K., Peduzzi, M., Sangaleti, C., Yonekura, T., \& Silva, D. R. A. D. (2014). Integrative review: concepts and methods used in nursing. Revista da Escola de Enfermagem da USP, 48(2), 335-345. https://doi.org/10.1590/S00806234201400002000020

Souza, L. V., \& Santos, M. A. (2009). A construção social de um grupo multifamiliar no tratamento dos transtornos alimentares. Psicologia: Reflexão e Crítica, 22(3), 317-326. https://doi. org/10.1590/S0102-79722009000300020

Souza, L. V., \& Santos, M. A. (2012). Familiares de pessoas diagnosticadas com transtornos alimentares: participação em atendimento grupal. Psicologia: Teoria e Pesquisa, 28(3), 325-334. https://doi.org/10.1590/S0102-37722012000300008

Souza, L. V., \& Santos, M. A. (2015). Histórias de sucesso de profissionais da saúde no tratamento dos transtornos alimentares. Psicologia: Ciência e Profissão, 35(2), 528-542. https://doi.org/10.1590/1982-370300132013

Strauch, F. C. (2013). Do pai no texto freudiano ao pai da contemporaneidade: um estudo teórico (Dissertação de Mestrado). Pontifícia Universidade Católica do Rio de Janeiro, Rio de Janeiro, RJ, Brasil. https://doi.org/10.17771/PUCRio. acad.23895 Disponível em: https://www.maxwell.vrac.puc-rio. br/23895/23895.PDF

Treasure, J., \& Schmidt, U. (2013). The cognitive interpersonal maintenance model of anorexia nervosa revisited: a summary of the evidence for cognitive, socio-emotional and interpersonal predisposing and perpetuating factors. Journal of Eating Disorders, 1, 1-10. https://doi.org/10.1186/20502974-1-13

Treasure, J., Schmidt, U., \& Kan, C. (2019). An illustration of collaborative care with a focus on the role of fathers in Maudsley Anorexia Nervosa Treatment for Adults (MANTRA). Journal of Clinical Psychology, 75, 1403-1414. https://doi.org/10.1002/jclp.22789

Valdanha, E. D., Scorsolini-Comin, F., Peres, R. S., \& Santos, M. A. (2013). Influência familiar na anorexia nervosa: em busca das melhores evidências científicas. Jornal Brasileiro de Psiquiatria, 62(3), 225-233. https://doi.org/10.1590/S004720852013000300007

Valdanha-Ornelas, E. D., \& Santos, M. A. (2016a). O percurso e seus percalços: itinerário terapêutico nos transtornos alimentares. Psicologia: Teoria e Pesquisa, 32(1), 169-179. https://doi. org/10.1590/0102-37722016012445169179

Valdanha-Ornelas, E. D., \& Santos, M. A. (2016b). Family psychic transmission and Anorexia Nervosa. Psico-USF, 21(3), 635649. https://doi.org/10.1590/1413-82712016210316

Vieira, J. A., \& Garrett, J. M. (2005). Understanding interobserver agreement: the Kappa statistic. Family Medicine, 37(5), 360363.

Wallis, A., Miskovic-Wheatley, J., Madden, S., Rhodes, P., Crosby, R. D., Cao, L., \& Touyz, S. (2018). Family functioning and relationship quality for adolescents in family-based treatment with severe Anorexia Nervosa compared with non-clinical adolescents. European Eating Disorders Review, 26(1), 29-37. https://doi.org/10.1002/erv.2562. 